\title{
SHOREBIRD MIGRATION AT LUCK LAKE, SK
}

MICHAEL R. NORTON and GERARD W. BEYERSBERGEN, Canadian Wildlife Service, Environment Canada, \#200, 4999 - 98 Ave., Edmonton, AB T6B 2X3 mike.norton@ec.gc.ca \& gerard.beyersbergen@ec.gc.ca

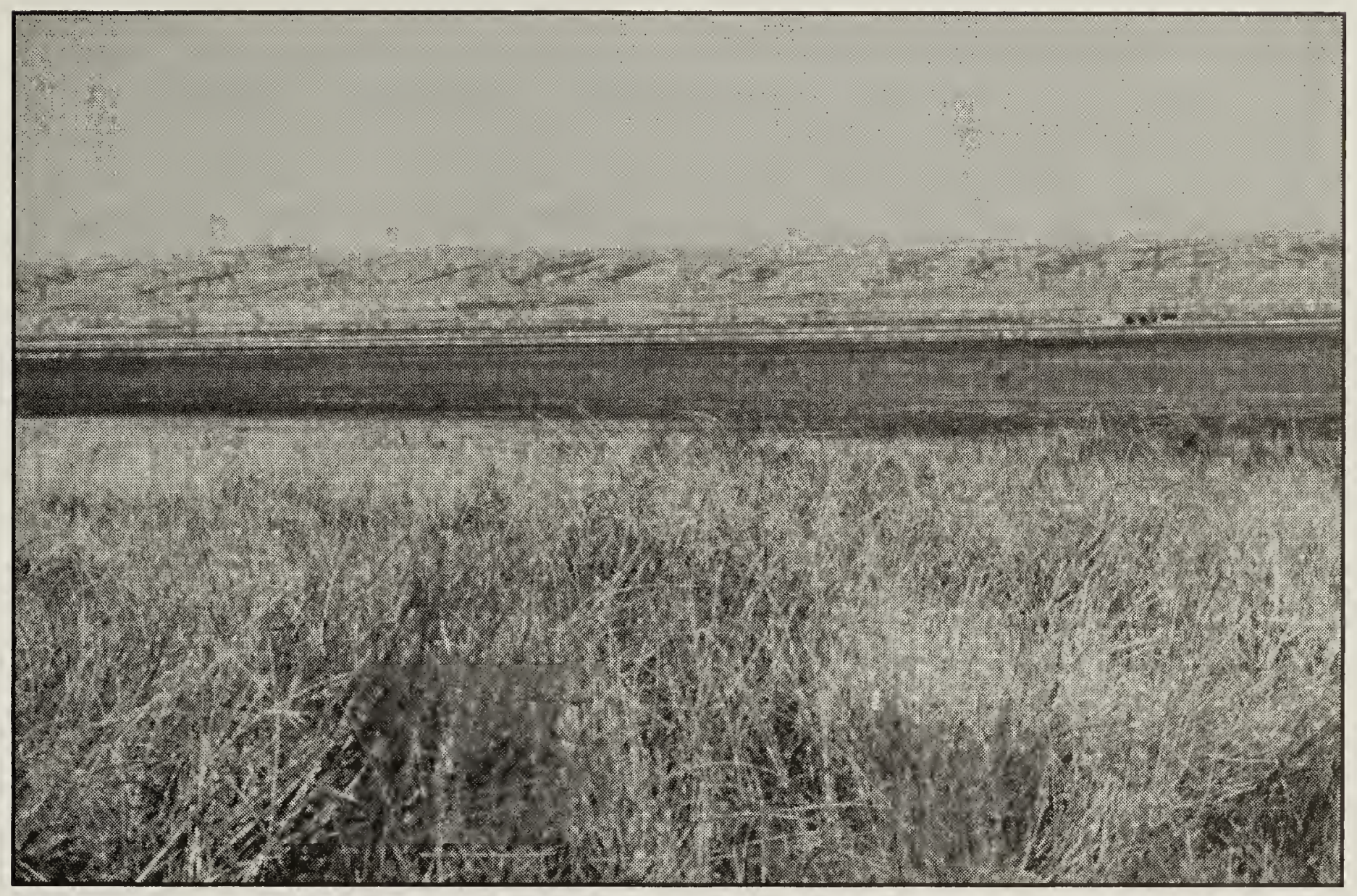

Lakes and wetlands in prairie Canada provide abundant habitat for shorebirds. Sixteen species breed regularly in Saskatchewan, and an additional 19 species migrate through the province each year but breed farther north. ${ }^{6}$ Shorebirds are capable of non-stop flights of thousands of kilometres during migration, fueled by energy stored as fat. Due to the distance between wintering and breeding areas, they must replenish their fat reserves at locations with suitable habitat. These "staging areas" are critical to shorebirds for the completion of their annual migration.

Saskatchewan contains several large wetland basins known to be important for migrating shorebirds. For example, the Quill Lakes and Chaplin/Old Wives Lakes each support hundreds of thousands of shorebirds each year. Surveys are ongoing to document other sites of critical importance to migrant shorebirds to help establish priorities for population monitoring and the conservation and management of key sites in accordance with a national strategy. ${ }^{3}$ It has been recognized that Luck Lake hosts large numbers of shorebirds during spring and fall migration, when habitat conditions are suitable, and the lake was surveyed 19891994 (M. Gollop, unpublished data) to document numbers of birds using this site. This article presents summary results from four years of surveys of migrant shorebirds conducted since 1996 at Luck Lake.

\section{Study Area}

Luck Lake $\left(51^{\circ} 4^{\prime} \mathrm{N} 107^{\circ} 6^{\prime} \mathrm{W}\right)$ is a 
shallow, alkaline lake located approximately $45 \mathrm{~km}$ south of Outlook. The lake is roughly oval in shape with maximum dimensions 8 $\mathrm{km} \times 5 \mathrm{~km}$, and approximately $27 \mathrm{~km}$ of shoreline. Historically, the lake was subject to highly variable water level conditions and periodically dried out completely. In 1987, however, a partnership of conservation organizations led by Ducks Unlimited Canada undertook development of the Luck Lake Heritage Marsh. The project involved construction of a water pipeline, dikes with water control structures, and other improvements. ${ }^{4}$ The lake now usually holds water in 2 of 3 basins, and marsh vegetation is developing in the east and west basins of the lake (Figure 2). The width of mud flats, the habitat most favoured by many shorebirds, varies with precipitation levels and the rate of water inflow through the pipeline. As is typical of shallow prairie lakes, water levels tend to be highest in the spring, and can be significantly lower in the late summer and fall.

Habitat conditions for shorebirds varied significantly during the years the surveys were done, but in all years there was suitable shorebird habitat. Water and open mud flats were present in the west basin in August 1995 but the central basin was nearly dry. Unfortunately, habitat conditions are unknown for the fall of 1996. Water levels were high in 1997 and on May 11 the basins in Luck Lake were full, with minimal shoreline habitat available or suitable for shorebird use. The following spring, water levels had receded and the southern shoreline of the central basin on May 21, 1998 had extensive mud flats varying in width from 5 to $15 \mathrm{~m}$. Shoreline mud flats continued to be exposed or expanded, and in July 1998 ranged in width from $10 \mathrm{~m}$ to $50 \mathrm{~m}$ around the central basin, with similar conditions

Figure 2. Map of Luck Lake. Public access points are indicated by a star.

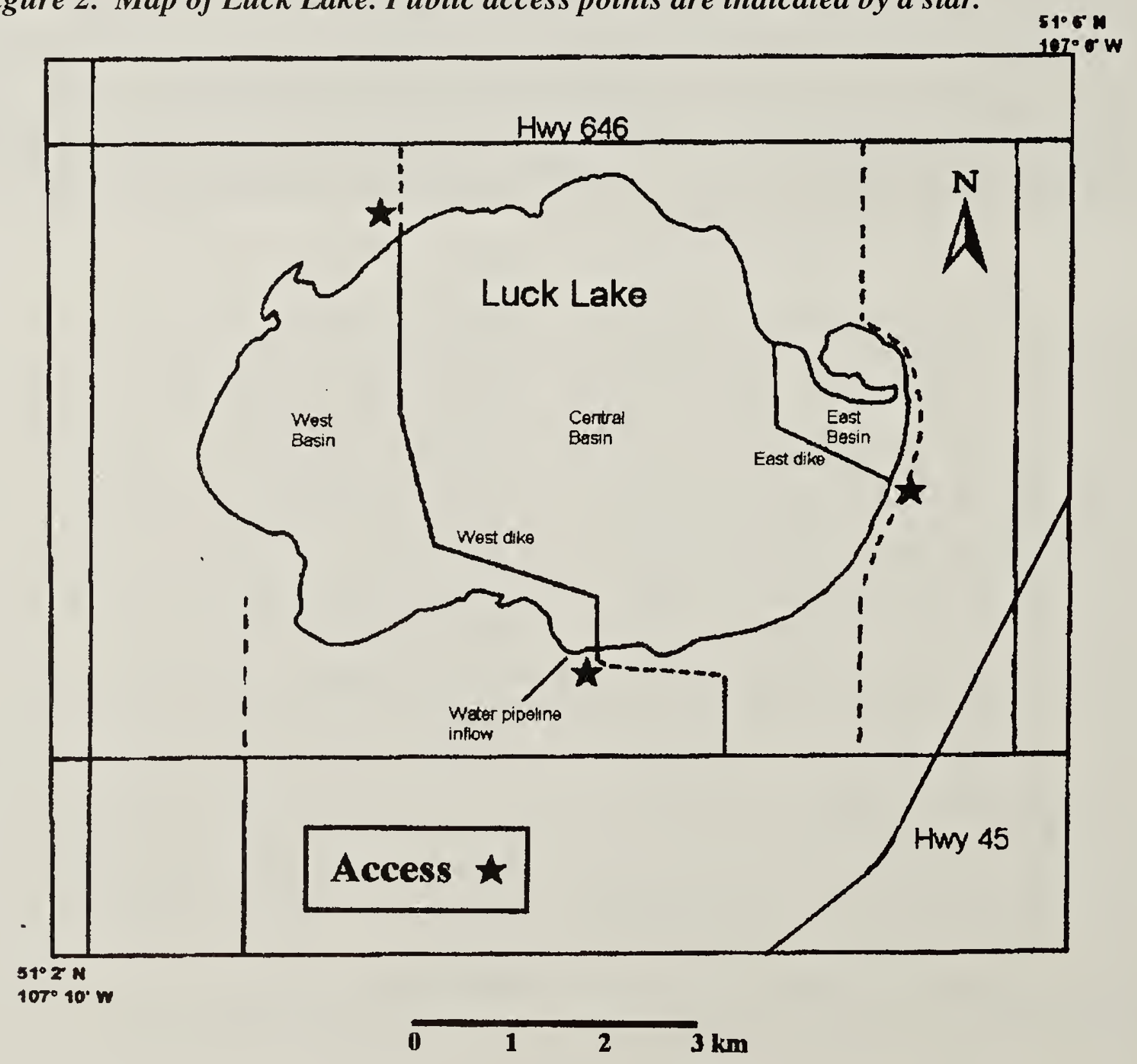


along the west side of the west basin. In 2001, shoreline mud flats were roughly 10 $\mathrm{m}$ to $50 \mathrm{~m}$ in width in the west and central basins, but continuing drought conditions led to very low water levels in spring 2002; mud flats were up to $500 \mathrm{~m}$ or more wide in the central basin, and the east basin was nearly dry.

\section{Methods}

Surveys were conducted in 1996, 1998, 2001, and 2002. Surveys in 1996 and 1998 focused on the fall migration period (midJuly to late September), and surveys in 2001 and 2002 focused on the spring migration period (early May to early June).

Because timing of migration varies with species, sex, and age of birds, repeated visits were made in each season to document all species which might use the lake. Each survey visit was completed within a single day, and most of the lake shoreline, including both dikes, was surveyed on each visit.
Surveys were most intensive in the fall of 1996 (9 visits) and spring of 2001 (5 visits), with only 3 visits in 1998 ( 1 spring, 2 fall), 1 in fall 2001, and 2 in spring 2002 (Table 1). Surveys were conducted by one or two observers using all terrain vehicles to travel along the upper edge of the mud flats. Surveys were never conducted in the rain, but due to a prevalence of high winds in the area, some surveys were conducted in winds up to $50 \mathrm{~km} / \mathrm{h}$. Birds were counted and identified using binoculars and/or a 15-60 power spotting scope. Occasionally, distance to groups of birds made species identification impossible and in such cases, birds were classified according to size as small, medium, or large. Poor visibility of the water's edge due to very wide mudflats in 2002 made identification particularly problematic.

Results are presented as daily total counts across all species (Table 1), or as peak oneday counts for individual species (Tables 2

Table 1: Total shorebird counts at Luck Lake, SK. Each count represents a full survey of the shoreline of the lake including both dikes. Numbers include birds which could not be identified to species.

\begin{tabular}{|c|c|c|c|c|c|}
\hline & \multirow{2}{*}{$\begin{array}{c}\begin{array}{c}\text { Relative } \\
\text { Abundance }\end{array} \\
\text { (Fall 1996) }\end{array}$} & \multicolumn{2}{|c|}{ Fall $1996^{a}$} & \multicolumn{2}{|c|}{ Fall $1998^{\circ}$} \\
\hline & & $\begin{array}{c}\text { Max } \\
\text { Number }\end{array}$ & $\begin{array}{l}\text { Max } \\
\text { Date }\end{array}$ & $\begin{array}{c}\text { Max } \\
\text { Number }\end{array}$ & $\begin{array}{l}\text { Max } \\
\text { Date }\end{array}$ \\
\hline Dowitcher sp. & 43.55 & 4,951 & 5 Sept. & 3,812 & $17 \mathrm{July}$ \\
\hline Yellowlegs sp. & 22.21 & 2,528 & 21 Aug. & 3,958 & $17 \mathrm{July}$ \\
\hline Semipalmated Sandpiper & 9.12 & 1,703 & 21 Aug. & 263 & $17 \mathrm{July}$ \\
\hline Stilt Sandpiper & 4.96 & 935 & 28 Aug. & 2,575 & $17 \mathrm{July}$ \\
\hline Wilson's Phalarope & 4.47 & 706 & 31 July & 490 & 17 July \\
\hline Hudsonian Godwit & 2.15 & 320 & 24 July & 553 & 19 July \\
\hline Black-bellied Plover & 1.15 & 155 & 21 Aug. & 8 & $17 \mathrm{July}$ \\
\hline Willet & 1.02 & 124 & 31 July & 404 & 17 July \\
\hline Marbled Godwit & 1.01 & 285 & 21 Aug. & 473 & $17 \mathrm{July}$ \\
\hline Pectoral Sandpiper & 0.99 & 121 & 21 Aug. & 71 & $19 \mathrm{July}$ \\
\hline American Avocet & 0.82 & 86 & 18 July & 69 & $19 \mathrm{July}$ \\
\hline Red-necked Phalarope & 0.72 & 178 & $18 \mathrm{July}$ & 304 & $17 \mathrm{July}$ \\
\hline Baird's Sandpiper & 0.52 & 85 & 31 July & 17 & 19 July \\
\hline Sernipalmated Plover & 0.24 & 97 & 31 July & 63 & 19 July \\
\hline Killdeer & 0.10 & 9 & 14 Aug. & 46 & $17 \mathrm{July}$ \\
\hline Sanderling & 0.08 & 26 & 12 Sept. & 1 & 17 July \\
\hline American Golden-Plover & 0.04 & 16 & 5 Sept. & - & - \\
\hline Common Snipe & 0.04 & 6 & 28 Aug. & - & - \\
\hline Spotted Sandpiper & 0.02 & 3 & $12 \mathrm{July}$ & 4 & $19 \mathrm{July}$ \\
\hline Piping Plover & $<0.01$ & 1 & 31 July & 2 & 19 July \\
\hline Ruddy Turnstone & $<0.01$ & 2 & 21 Aug. & 2 & 17 July \\
\hline Least Sandpiper & - & - & - & 40 & 19 July \\
\hline
\end{tabular}

a $=9$ survevs (12 Julv. 18 Julv. 24 Julv. 31 Julv. 14 Aug.. 21 Aug., 28 Aug.. 5 Sept., 12 Sept.) 
Table 2: Maximum daily total counts of shorebirds at Luck Lake, SK during spring migration 2001 and 2002. The date on which the maximum count occurred is shown. Relative abundance of shorebirds in spring 2001 is the percentage of the total count across all 5 visits in that year.

\begin{tabular}{|c|c|c|c|c|c|}
\hline & \multirow{2}{*}{$\begin{array}{c}\text { Relative } \\
\text { Abundance } \\
\text { (Spring 2001) }\end{array}$} & \multicolumn{2}{|c|}{ Spring $2001^{\mathrm{a}}$} & \multicolumn{2}{|c|}{ Spring $2002^{b}$} \\
\hline & & $\begin{array}{c}\text { Max } \\
\text { Number }\end{array}$ & $\begin{array}{l}\text { Max } \\
\text { Date }\end{array}$ & $\begin{array}{c}\text { Max } \\
\text { Number }\end{array}$ & Max Date \\
\hline Semipalmated Sandpiper & 29.73 & 13,635 & 21 May & 1,668 & 25 May \\
\hline Red-necked Phalarope & 23.38 & 14,881 & 21 May & 2,217 & 25 May \\
\hline Stilt Sandpiper & 15.87 & 7,319 & 21 May & 597 & 16 May \\
\hline Sanderling & 10.01 & 6,645 & 2 June & 389 & 25 May \\
\hline Baird's Sandpiper & 6.68 & 1,855 & 21 May & 1,728 & 16 May \\
\hline American Avocet & 4.44 & 997 & 12 May & 197 & 25 May \\
\hline Dowitcher sp. & 3.95 & 3,217 & 12 May & - & - \\
\hline Black-bellied Plover & 1.70 & 727 & 21 May & 148 & 25 May \\
\hline Pectoral Sandpiper & 0.92 & 947 & 21 May & 77 & 16 May \\
\hline Willet & 0.46 & 107 & 16 May & 53 & 16 May \\
\hline Wilson's Phalarope & 0.44 & 220 & 12 May & 6 & 16 May \\
\hline Marbled Godwit & 0.22 & 88 & 12 May & 16 & 25 May \\
\hline American Golden-Plover & 0.13 & 78 & 12 May & - & - \\
\hline Least Sandpiper & 0.11 & 95 & 21 May & 23 & 25 May \\
\hline Yellowlegs sp. & 0.10 & 65 & 12 May & 3 & 16 May \\
\hline Semipalmated Plover & 0.09 & 63 & 21 May & 4 & 25 May \\
\hline Dunlin & 0.06 & 17 & 23 May & - & - \\
\hline Red Knot & 0.03 & 10 & 23 May & 2 & 16 May \\
\hline Ruddy Turnstone & 0.03 & 13 & 21 May & - & - \\
\hline White-rumped Sandpiper & 0.03 & 30 & 16 May & - & - \\
\hline Killdeer & 0.02 & 7 & 12 May & 3 & 16 May \\
\hline Whimbrel & 0.02 & 19 & 16 May & - & - \\
\hline Hudsonian Godwit & 0.01 & 12 & 12 May & - & - \\
\hline Spotted Sandpiper & 0.01 & 6 & 16 May & - & - \\
\hline Common Snipe & $<0.01$ & 3 & 12 May & - & - \\
\hline Piping Plover & $<0.01$ & 2 & 2 June & 1 & 25 May \\
\hline Upland Sandpiper & - & - & - & 2 & 25 May \\
\hline Long-billed Curlew & - & - & - & 1 & 25 May \\
\hline
\end{tabular}

${ }^{a} n=5$ surveys (12 May, 16 May, 21 May, 23 May, 2 June)
${ }^{n} n=2$ surveys (16 May, 25 May)

and 3). Because of unknown lengths of stay and turnover rates of the various species, it is not appropriate to calculate species totals by summing counts made on successive visits. All numbers presented are therefore extremely conservative of the actual total numbers of birds using Luck Lake.

\section{Results and Discussion}

Twenty-eight shorebird species were 
Table 3: Maximum daily total counts of shorebirds at Luck Lake, SK during fall migration 1996 and 1998. The date on which the maximum count occurred is shown. Relative abundance of shorebirds in fall 1996 is the percentage of the total count across all 9 visits in that year.

\begin{tabular}{|c|c|c|c|c|c|}
\hline & \multirow{2}{*}{$\begin{array}{c}\text { Relative } \\
\text { Abundance } \\
\text { (Fall 1996) }\end{array}$} & \multicolumn{2}{|c|}{ Fall $1996^{\mathrm{a}}$} & \multicolumn{2}{|c|}{ Fall $1998^{6}$} \\
\hline & & $\begin{array}{c}\text { Max } \\
\text { Number }\end{array}$ & $\begin{array}{l}\text { Max } \\
\text { Date }\end{array}$ & $\begin{array}{c}\text { Max } \\
\text { Number }\end{array}$ & $\begin{array}{l}\text { Max } \\
\text { Date }\end{array}$ \\
\hline Dowitcher sp. & 43.55 & 4,951 & 5 Sept. & 3,812 & 17 July \\
\hline Yellowlegs sp. & 22.21 & 2,528 & 21 Aug. & 3,958 & 17 July \\
\hline Semipalmated Sandpiper & 9.12 & 1,703 & 21 Aug. & 263 & 17 July \\
\hline Stilt Sandpiper & 4.96 & 935 & 28 Aug. & 2,575 & 17 July \\
\hline Wilson's Phalarope & 4.47 & 706 & 31 July & 490 & 17 July \\
\hline Hudsonian Godwit & 2.15 & 320 & 24 July & 553 & 19 July \\
\hline Black-bellied Plover & 1.15 & 155 & 21 Aug. & 8 & 17 July \\
\hline Willet & 1.02 & 124 & 31 July & 404 & 17 July \\
\hline Marbled Godwit & 1.01 & 285 & 21 Aug. & 473 & 17 July \\
\hline Pectoral Sandpiper & 0.99 & 121 & 21 Aug. & 71 & 19 July \\
\hline American Avocet & 0.82 & 86 & 18 July & 69 & 19 July \\
\hline Red-necked Phalarope & 0.72 & 178 & 18 July & 304 & 17 July \\
\hline Baird's Sandpiper & 0.52 & 85 & 31 July & 17 & 19 July \\
\hline Semipalmated Plover & 0.24 & 97 & 31 July & 63 & 19 July \\
\hline Killdeer & 0.10 & 9 & 14 Aug. & 46 & 17 July \\
\hline Sanderling & 0.08 & 26 & 12 Sept. & 1 & 17 July \\
\hline American Golden-Plover & 0.04 & 16 & 5 Sept. & - & - \\
\hline Common Snipe & 0.04 & 6 & 28 Aug. & - & - \\
\hline Spotted Sandpiper & 0.02 & 3 & 12 July & 4 & 19 July \\
\hline Piping Plover & $<0.01$ & 1 & 31 July & 2 & 19 July \\
\hline Ruddy Turnstone & $<0.01$ & 2 & 21 Aug. & 2 & 17 July \\
\hline Least Sandpiper & - & - & - & 40 & 19 July \\
\hline
\end{tabular}

${ }^{a} n=9$ surveys (12 July, 18 July, 24 July, 31 July, 14 Aug., 21 Aug., 28 Aug., 5 Sept., 12 Sept.)

${ }^{\mathrm{b}} \mathrm{n}=2$ surveys (17 July, 19 July)

positively identified at Luck Lake over the 4 years of surveys: Black-bellied Plover, American Golden-Plover, Piping Plover, Semipalmated Plover, Killdeer, American Avocet, Greater Yellowlegs, Lesser Yellowlegs, Willet, Spotted Sandpiper, Upland Sandpiper, Whimbrel, Long-billed Curlew, Hudsonian Godwit, Marbled Godwit, Ruddy Turnstone, Red Knot, Sanderling, Dunlin, Pectoral Sandpiper, White-rumped Sandpiper, Baird's
Sandpiper, Semipalmated Sandpiper, Least Sandpiper, Stilt Sandpiper, Common Snipe, Wilson's Phalarope, Red-necked Phalarope. In addition, Long-billed Dowitcher and Short-billed Dowitcher were not distinguished and were grouped together as Dowitcher species, but both species may have been present. The number of species compares very favourably with the 35 shorebird species (including two species of dowitchers) considered to be of regular 
occurrence in the province. ${ }^{6}$ Although this study did not document breeding, eight of these species could be expected to breed at the lake, while the other species are migrants using the lake only for resting and feeding during migration. Of the 28 species, two (Upland Sandpiper and Long-billed Curlew) were associated with upland habitats while the remaining 26 species were found using the lake, lakeshore, or marsh habitats.

In general, daily counts of shorebirds were higher during the spring migration period (early May to early June) than in the fall migration period (mid-July to late September, Table 1). This is to be expected partly because the northward migration of shorebirds occurs over a much shorter time frame, concentrating the birds and providing higher counts on one day. Spring numbers peak in approximately the third week of May, coinciding with the peak migration of several abundant species including Rednecked Phalarope and Semipalmated Sandpiper. The peak number in spring 2001, nearly 45,000 birds counted on 21 May 2001 , was substantially higher than the peak of 15,000 reported previously. ${ }^{4}$ By totaling the peak number for each species in 2001, we estimate that over 51,000 shorebirds used the site during the spring migration (Table 2). The actual number of birds using the lake will be substantially higher, but it is impossible to arrive at a number without information on the length of stay of individual birds and turnover rates for each species. However, it is clear that large numbers of migrants use the lake from at least 12 May to 2 June, and probably up to a week earlier and later than these dates.

The peak of the fall migration in 1996 , on 21 August, was 8,278 birds, but a one day count on 17 July 1998 tallied 12,764 birds. This is only slightly lower than previous total counts made at the lake during fall migration: 14,427 on 28 July 1989 and 16,308 on 30 July 1992 (M. Gollop, unpublished data). Because only 2 surveys were completed in fall 1998, both in the second week in July, it can only be concluded that peak fall migration may occur between late July and late August; this is confirmed by Mike Gollop's observations. In all years except 1996, shorebird numbers were highest in the west basin of the lake. In fall 1996, the central basin held the greatest numbers of birds. When it held water, the east basin attracted numbers of dowitchers and Stilt Sandpipers.

Spring migration was dominated by five species: Semipalmated Sandpiper, Rednecked Phalarope, Stilt Sandpiper, Sanderling, and Baird's Sandpiper, as well as dowitchers (Table 2). In 2001, these made up $86 \%$ of all birds counted on the five surveys. Dowitchers were the first to peak, with maximum count of 3,217 on 12 May. The maximum count of American Avocet, a local breeder, occurred on the same day with 997 birds. The other five dominant species peaked on 21 May, except Sanderling, a species known to be a late migrant, which peaked on 2 June 2001.

In the fall, dowitchers were again very abundant with a maximum count of 4,951 on 5 September 1996, and were more frequently counted than other species across all survey visits (Table 3). Most other species abundant in spring were much less so in the fall. One species group which was notably more abundant in fall than in spring was the yellowlegs. Large numbers of yellowlegs, mostly Lesser Yellowlegs, were recorded during fall migration: 2,528 on 21 August 1996 and 3,837 on 17 July 1998.

Of particular note in the fall at Luck Lake are the Hudsonian Godwits. One of the authors (GWB) observed 3,357 Hudsonian Godwits on August 3, 1995 and although this study only recorded several hundred in late July of both 1996 and 1998, other reports of up to 3,500 to 4,000 have been published. ${ }^{4,5}$ Only one higher total count of this species has ever been published: 6,850 at Cheyenne Bottoms, Kansas. ${ }^{5}$ This poorly understood species is not often 
recorded in large numbers, and a concentration of this magnitude is of global significance.

The endangered Piping Plover was also recorded at Luck Lake in all 4 years of this study, but it is not known to breed there. Species composition and peak counts recorded in this study were similar to those previously reported (M. Gollop, unpublished data).

Overall, species composition and relative numbers of migrant shorebirds were very similar to those observed at the Quill Lakes ${ }^{1}$ and Last Mountain Lake. ${ }^{2}$ The most notable difference between Luck Lake and the Quill Lakes was the higher proportion of dowitchers and lower proportion of Whiterumped Sandpipers at Luck Lake. Chronology of migration was also similar at these two locations.

The extreme annual variation in habitat conditions, so characteristic of prairie wetlands, was observed in this study. Habitat conditions in May 2001 were nearly ideal for migrant shorebirds, with large areas of mud flats, shallow water, and deeper water. However, by May 2002 water levels had receded significantly despite an influx of water from the pipeline, leaving only small bodies of water in the center of the west and central basins. Migrant shorebirds showed their ability to adjust to changes in available habitat with the peak total number of birds declining by almost $90 \%$ in 2002 (Table 1). Although only two full surveys were completed in spring 2002 (16 and 25 May), a quick visual scan of the lake on 20 May revealed roughly only 6,000 birds, suggesting that the reduction in numbers in 2002 was not due to having missed the peak of migration in that year. The lower total numbers in spring 2002 were due to a reduction in numbers of all species, and the same species were numerically dominant in both 2001 and 2002. There is some evidence of increased numbers at the lake in fall 1998 over fall 1996, but a greatly reduced survey period makes it difficult to draw conclusions about annual variation in the fall migration. A comparison of habitat conditions between the two fall periods could potentially explain some of the differences, but the absence of habitat information for 1996 makes this impossible.

\section{Conclusion}

It is clear from the results presented here that Luck Lake is an important staging area for many species of shorebirds, although the level of use varies significantly between years. The large numbers of some prairie breeding species such as Willet, Marbled Godwit, and American Avocet suggest that the lake is also important to local breeders. Luck Lake has already been recognized as an Important Bird Area because of its use by congregatory species such as Tundra Swan, Greater White-fronted Goose and Lesser Snow Goose, and is included in the Saskatchewan Heritage Marsh Program. The survey results from this study indicate that the lake should also be considered for nomination under the Western Hemisphere Shorebird Reserve Network. The attention that has already been drawn to this site, plus the ability to manage water levels to some degree, all point to the fact that this site will continue to be one of key importance to shorebirds well into the future.

\section{Acknowledgments}

Sincere thanks are extended to Bob Neufeldt, with the Saskatchewan Wetland Conservation Corporation (SWCC), who conducted the 1996 surveys, as well as to Kevin Cantelon and Trisha Lang who assisted the authors in 1998 and 2002, respectively. Mike Gollop kindly provided unpublished results of his previous surveys of Luck Lake. Careful reviews by Anna Leighton improved the article. This work was funded by the Canadian Wildlife Service of Environment Canada and in partnership with the SWCC in 1996.

1. ALEXANDER, S. A. and C. L. GRATTOTREVOR 1997. Shorebird migration and staging 
at a large prairie lake and wetland complex: the Quill Lakes, Saskatchewan. Occasional Paper No. 97, Canadian Wildlife Service, Environment Canada, Ottawa, ON. 47 pp.

2. COLWELL, M. A. 1987. Seasonal shorebird abundance at Last Mountain Lake Wildlife Management Unit. Blue Jay 45:251266.

3. DONALDSON, G. M., C. HYSLOP, R. I. G. MORRISON, H. L. DICKSON, I. DAVIDSON. 2000. Canadian Shorebird Conservation Plan. Canadian Wildlife Service, Environment Canada, Ottawa, ON. 27 pp.
4. ROY, J. F. 1996, Birds of the Elbow. Special Publication No. 21, Saskatchewan Natural History Society, Regina, SK. 325 pp.

5. SKAGEN, S. K., P. B. SHARPE, R. G. WALTERMIRE, M. B. DILLON. 1999. Biogeographical profiles of shorebird migration in midcontinental North America. U. S. Geological Service Biological Science Report USGS/BRD/BSR-2000-0003.

6. SMITH, A. R. 1996. Atlas of Saskatchewan Birds. Special Publication No. 22, Saskatchewan Natural History Society, Regina, SK. 456 pp.

\section{THREE TURKEY VULTURE PAIRS NEST IN SASKATOON BIRD AREA}

C. STUART HOUSTON, 863 University Drive, Saskatoon, SK S7N 0J8, MARTEN J. STOFFEL, Box 183, RR\#4, Saskatoon, SK S7K 3J7, and ALAN R. SMITH, Canadian Wildlife Service, 115 Perimeter Road, Saskatoon, SK S7N 0X4

Turkey Vultures were regularly seen on the treeless plains while bison were present, and until at least $1890 .{ }^{4}$ They appeared in the Cypress Hills and Big Muddy badlands, along the Qu'Appelle and North and South Saskatchewan rivers, near lakes in Moose Mountain and along the southern edge of the boreal forest from Loon Lake to Duck Mountain. The first twelve nests recorded in Saskatchewan were in caves in cliffs or on the ground in nearly impenetrable dense tangles of underbrush. ${ }^{3,7}$ Only since 1983 and 1984 have Saskatchewan vultures been reported nesting, (as they have done in Illinois since $1978,{ }^{2}$ ) in attics of deserted houses, such as one north of Biggar, ${ }^{8}$ one north of Preeceville, ${ }^{1}$ and one west of Turtle Lake (Muriel Carlson, pers. comm.). During 2002, three widely separated pairs, each successful and each on the upper floor of a deserted farmhouse, provided the first definitive proof of Turkey Vultures breeding in the Saskatoon Bird Area (SBA; $51^{\circ} 32^{\prime}$ to $52^{\circ} 30^{\prime}$ north latitude and $106^{\circ}$ to $107^{\circ}$ $30^{\prime}$ west longitude).

On 6 June, Al Smith observed an adult Turkey Vulture on the roof of an abandoned farmhouse $4 \mathrm{~km}$ south and $3.2 \mathrm{~km}$ east of

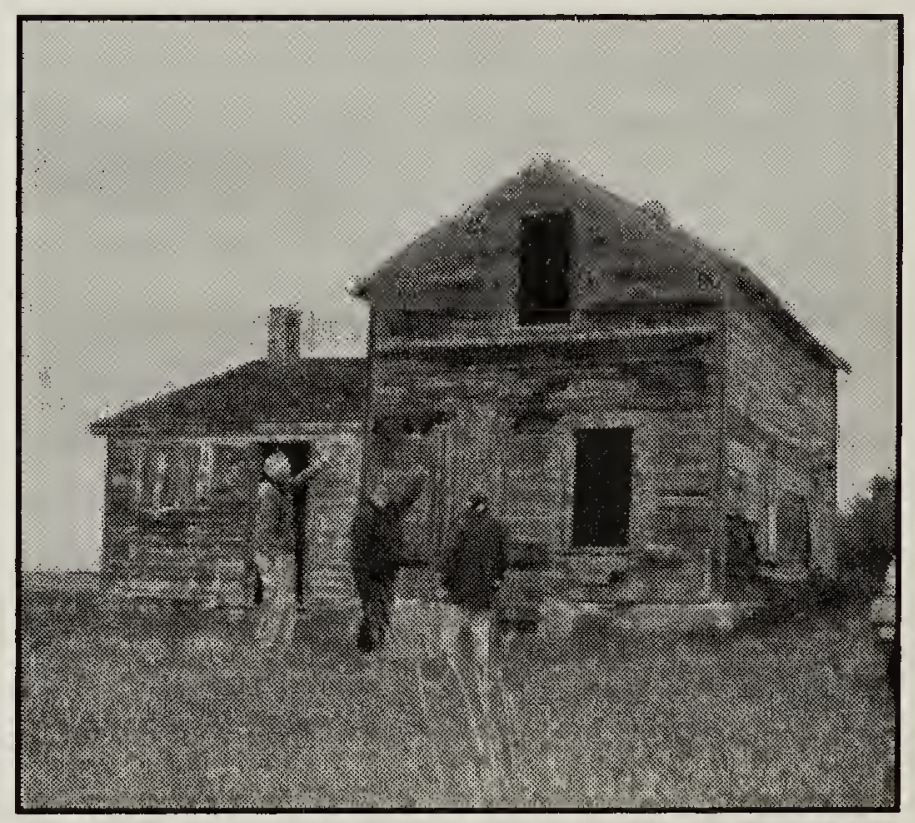

Figure 1. Judy Terry and Stuart pointing to second story window entrance to Turkey Vulture nest near Hanley. Brenton Terry 